\title{
425. 六ヶ所再処理工場運転訓練シミュレータの開発
}

\author{
小澤 敏宏 ${ }^{1}$, 脇元 広海 ${ }^{1}$, 山岡 功 ${ }^{1}$, 青柳 春樹 1 , 武内 豊 2 ,*, \\ 荒川 秋雄 ${ }^{2}$, 中村 健二 ${ }^{2}$, 柳川 幸喜 ${ }^{2}$, 瀧澤 洋二 ${ }^{2}$, 中久木 功 2
}

Development of Operator Training Simulator for Rokkasho Reprocessing Plant

Toshihiro OZAWA, Hiromi WAKIMOTO, Isao YAMAOKA, Haruki AOYAGI, Yutaka TAKEUCHI, Akio ARAKAWA, Kenji NAKAMURA, Kouki YANAGAWA, Yoji TAKIZAWA and Isao NAKAKUKI

\begin{abstract}
The operator training simulator has been started to develop for the purpose of safety and stable operation in the Rokkasho reprocessing plant, the first commercial spent nuclear fuel reprocessing plant in Japan. At present, the safety training simulator, which had been developed for the purpose of the specified abnormal events training, has already been in operation. The simulator was designed to contribute to the acquisition of the knowledge and skills indispensable for the plant operators and to the promotion of good team-work among operators. It was also designed in consideration of the simple and consistent extensibility to the full-scope training simulator which is now planned to develop using the same hard-ware. The model building and maintenance tools were applied as trial for the model tuning and modification. They must be indispensable for the reflection of the plant operation data and for the planning full-scope training simulator development. The usefulness and the validity of the simulator were ascertained through the training and its reports as the simulator development successfulness.
\end{abstract}

KEYWORDS: Rokkasho reprocessing plant, operator training simulator, safety training simulator, training scenario, model building tool, maintenance tool, full-scope training simulator

\section{I.はじめに}

青森県六ケ所村にて建設が進む日本原然株再処理工場 は，国内初の民間による軽水炉使用済み燃料再処理工場で ある。その年間最大処理能力は $800 \mathrm{tU}$ で, これは100万 $\mathrm{kW}$ 級原子力発電所約 30 基分の使用済み燃料を処理する能 力に相当する。水・蒸気・空気を用いた通水作動試験, 再 処理プロセスに使用される各種化学薬品を用いたケミカル 試験はほほ終了し，引き続き, ウラン試験, アクティブ試 験を経て，2006年度に操業を開始する予定である。

商業用の再処理施設は国内初であり, 安全かつ安定した 操業を行うために適切な技能・技術を備えた運転員を育成 する必要がある。そのため六ヶ所再処理工場では，運転員 の技術力向上・確保を目的に，世界でも類を見ない再処理 施設運転訓練シミュレータの設置を計画し，2001年 5 月 よりその開発が開始された。2003年 8 月には再処理工場 中央制御建屋に隣接した運転訓練施設に保安訓練シミュ レータが設置され，訓練が開始されている。

本報では，まず六ヶ所再処理工場におけるシミュレータ 訓練の目的を説明し，さらにそれに基ついて優先的に訓練 を開始すべき異常事象を選定したプロセス，選定された異

1 日本原燃株(Japan Nuclear Fuel Limited)

2 侏東芝(Toshiba Corporation)

(2004年6月25日 受理；2004年 10月14日 查読通過)

* 著者連絡先 : Tel. 045-770-2343, Fax. 045-770-2384,

E-mail: yutaka4.takeuchi@toshiba.co.jp
常事象の模擬範囲とその展開プロセスを説明する。次に， シミュレータの構成と特徵を述べた上で, プロセスモデル の開発・作成手法への新しい試みを説明する。むた，すで に開始されている運転訓練の概要と, 訓練から得られた知 見を説明した上で, 今後のシミュレータ開発の展開に関し て述べる。

\section{II. 開 発 背 景}

\section{1. 再処理工場の概要 ${ }^{1,2)}$}

六ヶ所再処理工場は，(1)一定期間，燃料貯蔵プールにて 冷却・貯蔵した使用済み燃料を細かく切断し, 燃料部分を 高温の硝酸を用いて溶解するせん断・溶解施設, (2)使用済 み燃料が溶解した硝酸溶液と有機溶媒とを接触させ，ウラ ン・プルトニウムと核分裂生成物を分離する分離施設，(3) 硝酸ウラニル溶液および硝酸プルトニウム溶液それぞれか ら，微量含まれている核分裂生成物をさらに取り除いて純 度を高める精製施設，(4)精製された硝酸ウラニル溶液と硝 酸プルトニウム溶液・硝酸ウラニル溶液の混合溶液からそ れぞれ硝酸を蒸発および熱分解させてウラン酸化物，ウラ ソ・プルトニウム鼬合酸化物として製品化し，それぞれの 貯蔵施設へと移送する脱硝施設，などから構成される。

これら再処理工場内に分散設置されている各施設の運 転・監視は中央制御室で集中的に行われる。中央制御室内 における監視制御盤(OIS : operator interface station)の配 置図を第 1 図に示す。この図からもわかるように，中央 制御室は馬蹄形をした 6 個のブロック(監視制御盤群)か 


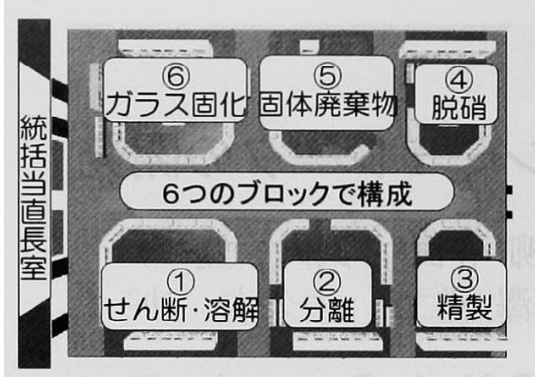

第 1 図 六ヶ所再処理工場中央制御室における監視制御盤の配 置

ら構成されている。各ブロックには監視・制御の対象とな る施設のプロセスデータなどを収集・管理する工程管理用 計算機と各ブロックをそれぞれ統括する当直長盤および安 全系監視制御盤が設置されており，膨大なデータを合理的 に処理する最新のデジタル制御と，監視操作画面のタッチ スクリーンおよび切替え機能により，設備を集中的に操 作·監視できるマンマシン・システムが採用されている。 6 個のブロック全体は統括当直長盤で統括管理を行い, 各 ブロックの工程管理用計算機とも連結されている。

\section{2. 設置目的および訓練のねらいと開発の展開}

六ヶ所再処理工場における運転訓練シミュレータ設置の 目的は,シミュレータ訓練を通じて再処理工場の安全かつ 安定な操業に必要な運転員の技術力向上とその確保を図 り，同時に各運転員の役割に応じた技能・技術の習得程度 を確認することである。このような目的から，運転員の技 術習得および異常事象が発生した際の的確な対応のための 訓練を行うべく，運転訓練シミュレータの開発を計画した。

運転訓練シミュレータによる訓練は再処理工場の施設別 (工程別) プロセス専門教育の一環として位置付けられてお り、この訓練を実施することで，

(1) プラントの特性理解

(2) 運転操作の体得

(3) 基本動作の体得

(4) 異常事象の理解

(5) 異常事象対応操作の体得

(6) 反復訓練による技術の習熟

(7) チームワークの醸成

(8) 試運転末経験者の運転操作の体得

等の項目を運転員に習得させることが訓練のねらいである。

また，これらの項目の習得を図る時期の検討を行い，上 記(3)〜(7)項目については，実機試験を通じた運転員の技能 向上の過程やシミェレータ訓練の特長を勘案し, 実機ウラ ン試験前から先行的にシミュレータ訓練を開始し習得を図 ることとした。

(1)，(2)，(8)項目については, 実機のウラン試験時, アク ティブ試験時, 操業運転開始以降に収集される各種プラン トデータの反映によるシミュレーションモデルの精度向上
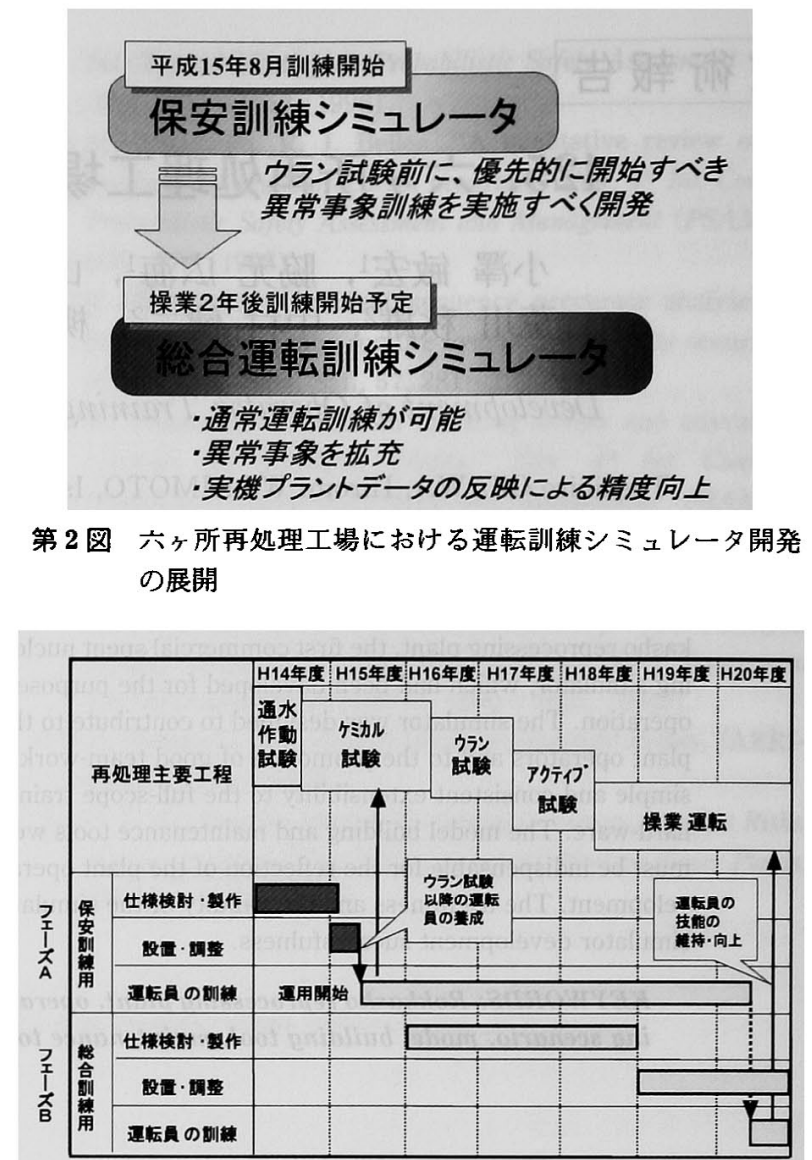

第 3 図 六ヶ所再処理工場における運転訓練シミュレータの開 発工程

必要性を踏まえ, 操業運転開始以降に習得を図るべく計画 した。

上記項目習得時期の計画を踏をえたシミュレータ開発展 開の概念図を第 2 図に，またシミュレータ開発工程を再 処理工場主要工程とともに第 3 図に示す。今回開発を実 施した運転訓練シミュレータは上記(3)〜(7)項目までの習得 訓練を目的とした保安訓練シミュレータ(フェーズA)で ある。再処理工場操業開始後において, 上記 8 項目すべ ての習得を含む，総合的な運転訓練を実施するための次期 開発予定フルスコープシミュレータが総合運転訓練シミュ レータ(フェーズB)である。このように運転訓練シミュ レータ開発は大きく2つのフェーズに分かれるが, 本報 では特に区別する必要がない場合には運転訓練シミュレー タと記述し，今回模擬した訓練事象を限定的に対象とする 場合には保安訓練シミュレータと記述する。

\section{III. 訓練事象選定}

今回開発を実施した保安訓練シミュレータは, 第 2 図 に示すように, 実機ウラン試験前に優先的に開始すべき異 常事象訓練を行うための設備であるため，その開発を始め るには，まず，訓練事象として「ウラン試験前に訓練を開 始すべき異常事象」を選定する必要がある。それに際し， 
今回は六ヶ所再処理工場に対する安全評価の知見を基に選 定を進めた。本章では，まず，六ヶ所再処理工場の安全評 価について概要を述べ，さらに選定に際して安全評価の知 見を採用した理由を述べた上で具体的な訓練事象選定プロ セスを説明する。

\section{1. 安全評価の概要}

六ヶ所再処理工場では，施設内の異常に対し第 4 図に 示すように,

- 異常の発生防止

・異常が発生したとしても，その拡大を防止する

・さらに，異常が事故に拡大した場合においても，その 影響を緩和する

という，多重防護の考えの基に安全設計を採っている。

安全評価とは，その多重防護の考え方が施設設計の基本 方針において適切に採用されていることを確認するために 行うもので,「運転時の異常な過渡変化 (AT : Anticipated Transient)」と「運転時の異常な過渡変化を超える事象 (BAT : Beyond Anticipated Transient)」という 2 種類に 分類して評価した ${ }^{3)}$ 。

前者は, 多重防護における異常の拡大防止対策の妥当性 を評価するために想定する事象であり，後者は，多重防護 における影響緩和対策の妥当性を評価するために想定す る,いわゆる事故事象である。

これら AT および BAT 事象を評価して，各事象への対 策の妥当性を判断するための流れを第 5 図に示す。
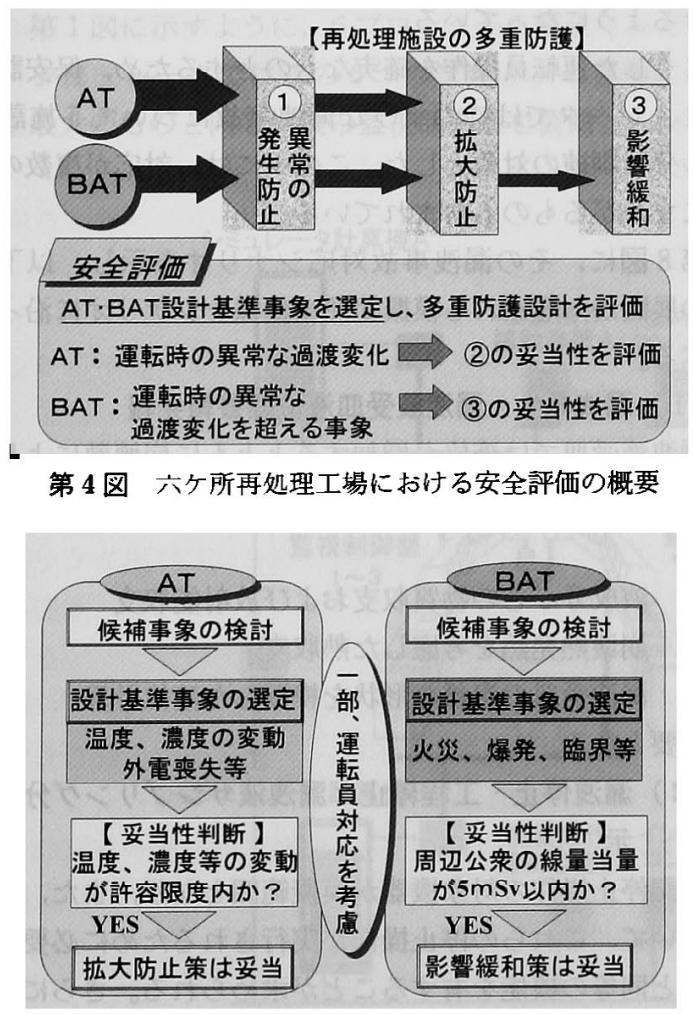

第 5 図 六ヶ所再処理工場に打ける安全評価の流れ
まず AT，BAT それぞれに設計基準事象を選定する必 要があるが，そのためにその候補となる事象を網羅的に洗 い出し，その中から多重防護設計の妥当性を確認する観点 に立ち設計基準事象とすべきものを選定した。その結果， $\mathrm{AT}$ では温度, 濃度の変動など, BATでは各種の事故事 象が選定された。次にこれらの事象の発生を想定した解析 を行い,それぞれの判断基準との比較により, 設計の妥当 性を評価した。判断基準としては, ATについては温度, 濃度などの変動が最大許容限度内であること, BATにつ いては周辺公衆への影響が線量当量で $5 \mathrm{~m} \mathrm{~Sv}$ 以内である ことである。なお，これらの判断基準は再処理施設安全審 查指針 (昭和61年原子力安全委員会決定 $)^{4}$ に基ついて設定 したものであり, 詳細については再処理事業指定申請書に 記載した5)。こうした六ヶ所再処理工場の安全評価につい ては，1989年から1992年にかけ実施された国による安全 審査において妥当性が確認されている。

ここで,これまでの一連の安全評価の流れの中では, 設 計基準事象の選定や，事象の評価の過程において，一部， 運転員の対応を想定している。

六ヶ所再処理工場において実際に使用済み燃料の再処理 を開始するにあたっては, 運転員はこの安全評価において 想定した対応を着実に実施できる技能を有する必要があ る。このため, ウラン試験前に訓練を行っておくべき訓練 事象としては,この安全評価中で運転員対応を想定したも のから選定した。

\section{2. 訓練事象選定のプロセス}

AT の安全評価については, 第 6 図に示すように, AT 設計基準事象はすべて運転員の対応を期待せずとも設備対 応済みであることが確認されている。をた, 設計基隼事象 とはならなかったAT候補事象のほとんどが，最大許容 限度に至るまでの時間余裕が十分あるものである。保安訓 練シミュレータの開発にあたっては，「運転員対応」とい う要素と「時間余裕の長さ」に着目し，AT 候補事象の中 から「時間的余裕が 1 日以内で運転員対応が必要な事象」 の3事象を保安訓練シミュレータの訓練事象として選定 した。

次に, 第 7 図に示すように, 火炎, 爆発, 臨界, 漏洩

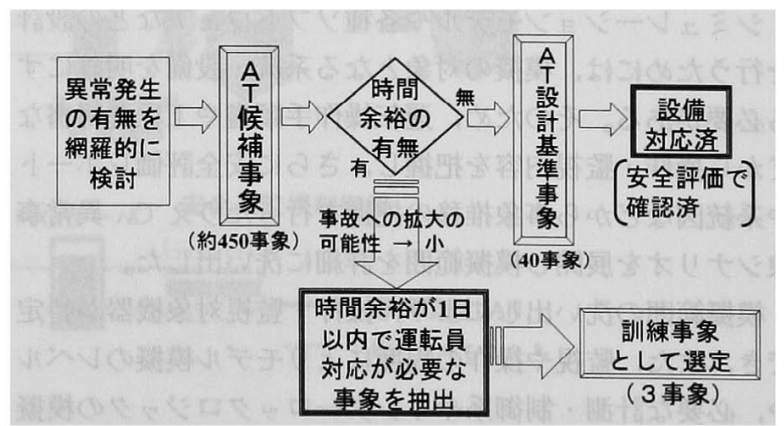

第 6 図AT の安全評価に基つく訓練事象選定 


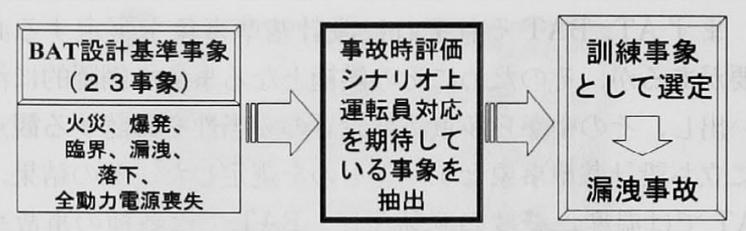

第 7 図 BAT の安全評価に基つく訓練事象選定

第 1 表 訓練事象とその特改

\begin{tabular}{|c|c|c|c|c|}
\hline 訓練事象 & $\begin{array}{l}\text { 異常の } \\
\text { 分類 }\end{array}$ & $\begin{array}{l}\text { 時間的 } \\
\text { 余禞 }\end{array}$ & 対応操作 & 対象施設 \\
\hline \multicolumn{5}{|l|}{ AT 事象からの選定 } \\
\hline $\begin{array}{l}\text { 溶解液供給流量低 } \\
\text { 下時の少う追出 } \\
\text { L槽過濃縮 }\end{array}$ & $\begin{array}{l}\text { 臨界 } \\
\text { の払大 }\end{array}$ & $\begin{array}{l}\text { 10時間 } \\
\text { 以上 }\end{array}$ & $\begin{array}{l}\text { 加熱蒸気 } \\
\text { 供給止 }\end{array}$ & せん断·溶 \\
\hline $\begin{array}{l}\text { 遠心清澄機に扔 } \\
\text { る不溶解渣排出 } \\
\text { 流量低下/排出時 } \\
\text { 回転不良 }\end{array}$ & $\begin{array}{l}\text { 溶解液 } \\
\text { 海榪 } \\
\text { の拡大 }\end{array}$ & $\begin{array}{l}2 \text { 時間 } \\
\text { 以上 }\end{array}$ & $\begin{array}{l}\text { 这水采/ } \\
\text { 七一の } \\
\text { 切換 }\end{array}$ & $\begin{array}{l}\text { せん断・溶 } \\
\text { 解 }\end{array}$ \\
\hline $\begin{array}{l}\text { 外電培失時の混畣 } \\
\text { 酸化物貯蔵室送䖝 } \\
\text { 機停止 }\end{array}$ & $\begin{array}{l}\text { 冷却機 } \\
\text { 能低下 }\end{array}$ & 24時間 & $\begin{array}{l}\text { 吸気側バ } \\
\text { イハス }\end{array}$ & 製品貯蔵 \\
\hline \multicolumn{5}{|l|}{ BAT 事象からの選定 } \\
\hline $\begin{array}{l}\text { 溶解槽セル等の漏 } \\
\text { 泹故(対象 } 13 セ \text { ) } \\
\text { ル) }\end{array}$ & $\begin{array}{l}\text { 放射性 } \\
\text { 物筫の } \\
\text { 大気中 } \\
\text { への拡 } \\
\text { 散 }\end{array}$ & $\begin{array}{l}\text { 沸点に } \\
\text { 晊るま } \\
\text { で }\end{array}$ & $\begin{array}{l}\text { 漏洩液の } \\
\text { 沸騰前で } \\
\text { の回収 }\end{array}$ & $\begin{array}{l}\text { せん断·溶 } \\
\text { 解 } \\
\text { 分離 } \\
\text { 精製 } \\
\text { 脱硝 } \\
\text { ガラス固化 }\end{array}$ \\
\hline
\end{tabular}

等といった事故事象が BAT 設計基準事象であり，それら が発生した場合の影響緩和対策の妥当性を判断するため, 事故評価を行った。このうち漏洩については,その評価シ ナリオ上, 運転員の対応操作を期待しているため，この点 を重要視し，5施設計13セルにおける漏沂事故を訓練事象 として選定した。

選定した訓練事象と, その分類, 時問的余裕, 運転員対 応操作をまとめて第 1 表に示す。また，これまで述べて きたものに加え，結果の重大性と事故教訓反映の観点か ら、プルトニウム溶液の誤移送による臨界事故についてむ 訓練事象として選定した。

\section{IV. 事象シナリオの展開}

\section{1. シナリオ展開の方法}

シミュレーションモデルや各種ソフトウェアなどの設計 を行うためには, 模擬の対象となる系統・設備を明確にす る必要がある。そのため, 運転操作手順書や工程説明書な どから操作・監視内容を把握し, さらに安全評価レポート や系統図などから事象推移の把握を行ったうえで, 異常事 象シナリオを展開し模擬範囲を詳細に洗い出した。

模擬範囲の洗い出しにより, 操作 - 監視対象機器が特定 でき，また，監視や操作の程度によりモデル模擬のレベル や，必要な計測・制御系やインターロックロシックの模擬 範囲を設定することができる。

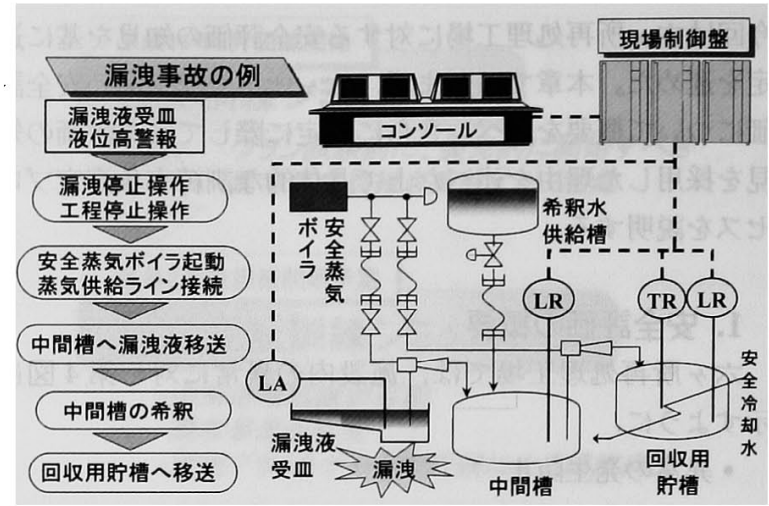

第 8 図 漏洩事故対応シナリオの例

なお，訓練事象は前章に述べたように限られてはいる が, 訓練事象の初期状態(通常運転時)の設定や, 異常時の 停止操作などが必要なため, 訓練事象に関連する一部の工 程に関しては, 基本的に運転手順書に沿った起動・停止操 作を可能とするほぼ全ての機器や制御系, インターロック ロジックなどが模擬対象となる。

次節で，展開した事象シナリオとそこから洗い出される 模擬範囲について, 漏洩事故の例を具体的に述ぺる。

\section{2. 漏洩事故のシナリオ展開例}

高レベル放射性物質を取り扱う機器等は, セルと呼ばれ る遮蔽壁で囲なれた部屋に収納されており, 万一, 溶液漏 洩が起きたとしても, その液を受ける漏洩液受皿, 漏洩検 知装置, 漏洩液移送機器を設置し, 運転員が速やかに回収 できるようになっている。

こうした運転員操作を確実なすのとするため, 保安訓練 シミュレータではこのような漏洩事故について 5 施設 13 セル分を訓練の対象とした。この中には, 対応が複数の施 設にまたがるものも含まれている。

第 8 図に，その漏洩事故対応シナリオを示し，以下に その展開から導かれる模擬範囲・仕様をシナリオに沿って 述べる。

\section{（1）漏沂発生·漏洩液受血液位高警報発報}

漏洩液受血では液位が増加するとともに崩壊熱により液 が昇温する。このため, 漏洩液受皿モデルの模擬仕様とし ては,
（a）液成分ごとの物質収支および放射能収支
(b) 崩壊熱発熱を考慮した熱収支
(c) 漏洩受血の複雑な形状を模擬した液位計算 が必要となる。

（2）漏洩停止 - 工程停止 - 漏洩液サンプリング分析指 示

上記停止操作の対象機器が模擬範囲となり, また, 実機 において，これらの停止操作が実行されるために必要な制 御系と同等の機能を有することが求められる。さらに工程 管理用計算機によるサンブリング分析要求 ·分析値表示模 
擬が必要となる。

(3) 安全蒸気ボイラ起動·蒸気供給ライン接続

漏洩液移送用スチームジェットポンプを使用する際に, 常用系に加え安全系の蒸気系統についてむ使用可能とする ため, 安全蒸気ボイラを起動し, 蒸気供給ラインを接続す る。実際にこれらの操作を実施する場合は現場建屋にて行 われるため, シミュレータによる現場操作模擬が求められ る。

（4）中間槽への漏洩液移送·希釈·回収用貯槽への移 送

冷却がなされている回収用貯槽へ移送する際, 液温が高 いことによるポンブ性能低下や漏洩液の過度の温度上昇を 防止するため，希釈操作を行う。このため中間槽および回 収用貯槽の模擬仕様としては

(a) 液成分ごとの物質収支および放射能収支

(b) 崩壤熱発熱, 希积, 冷却を考虑した熱収支

が必要々なる。また，漏洩液受血からの払出し状況につい ては安全系監視制御盤も使用して監視するため, 安全系監 視制御盤における警報抢よび液位指示機能の模擬が求めら れる。

\section{V. 運転訓練シミュレータの構成と特徵}

\section{1. 運転訓練シミュレータの構成}

運転訓練シミュレータの全体構成 ${ }^{6)}$ を第 9 図に示す。本 シミュレータでは，実機と同等のプラント応答や操作性と 臨場感等を満足するために，実機と同じ監視制御盤と画面 および制御ロシックを用いている。監視制御盤は実機で は，第 1 図に示すように，6ブロックから構成されている が, シミュレータではこの6つのブロックのうち, サイ ズが最大のものと同等規模の監視制御盤を装備し,シミュ
レーション用の物理化学プロセスモデルや監視操作用の画 面ソフト, インターロックロシック, 制御ロシックなど施 設固有の内蔵のソフトウェアを切り替えることにより，実 機の6ブロックすべてを模擬できる構成としている。た だし，保安訓練シミュレータでは，第 1 表で示された訓 練事象の対象とする5ブロック分を模擬している。すな わち, せん断 - 溶解施設, 分離施設, 精製施設, 脱硝施 設、および高レベル廃液ガラス固化施設である。

ブロセスモデルや制御ロシックなどの演算を行う計算機 サーバは A/B の 2 系統用意しているため, それに従って 監視制御盤む2 系統に分割して用いることが可能であ り，当直長盤やインストラクタコンソールもおのおの 2 系統用意されている。また，監視制御盤からは操作できな い現場操作機器に関しては, タッチスクリーン操作による 専用の模擬操作補助装置を設けることにより，シミュレー タからも現場操作模擬を可能にしている。

安全系監視制御盤は, 運転訓練にとって重要なアラーム 信号や安全系操作スィッチを選定して, 全施設 5 ブロッ ク分の安全系監視制御盤を 1 ブロック相当規模に縮約し て設置している。

インストラクタコンソールは, シミュレータ全体を見渡 せる 2 階のインストラクタ室に設置されているが，無線 LANを用いた携带用パソコンを用いて，シミュレータ室 の任意の場所においてもインストラクタ機能を使用するこ とができる。

第 2 表に運転訓練シミュレータの主な構成機器の機能 を実機と比較して示す。

\section{2. 運転訓練シミュレータの特徵}

運転訓練を効果的・效率的に行うために，本シミェレー

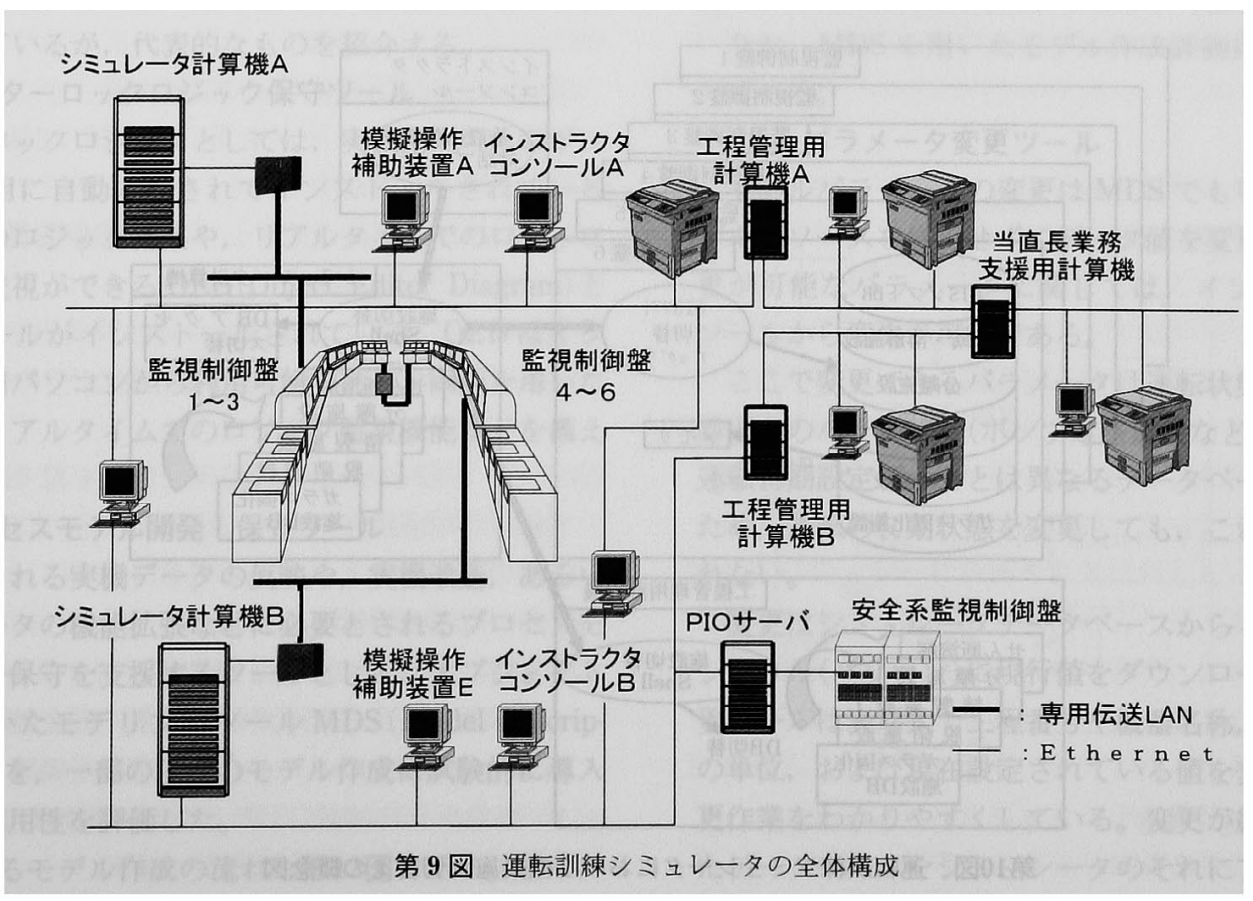

(99) 
タは以下のような特改を備えている。

（1）複数施設の訓練

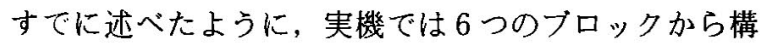
成されている監視制御盤群を，本シミュレータでは $17 ゙$ ロック相当のものを設置している。監視操作に関するハー ドウェア1ブロック(施設)に対し，ソフトウェアの部分 を切り替えることにより，複数の施設の訓練が可能にな る。具体的に切り替えられるソフトウェアは, シミュレー タ計算機(ロシック，データベース，プロセスモデルな

第 2 表 運転訓練シミュレータの主要機器·機能と実機との比較

\begin{tabular}{|c|c|c|c|}
\hline 役 割 & 機 器 & 機 能 & 実機との比較 \\
\hline \multirow[t]{3}{*}{$\begin{array}{l}\text { 運転· } \\
\text { 監視 }\end{array}$} & 監視制御盤 & $\begin{array}{l}\text { 再処理工場の备施設の } \\
\text { 転監視を行う }\end{array}$ & 実機同等 \\
\hline & $\begin{array}{l}\text { 晏全系監視制 } \\
\text { 御盤 }\end{array}$ & 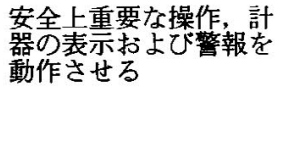 & 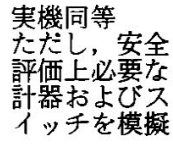 \\
\hline & $\begin{array}{l}\text { 模擬操作補助 } \\
\text { 装惪 }\end{array}$ & 現場操作を模擬する & なし \\
\hline \multirow[t]{3}{*}{$\begin{array}{l}\text { ブラン } \\
\text { ト制御 }\end{array}$} & 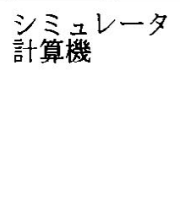 & 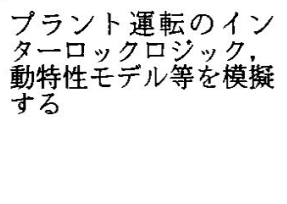 & 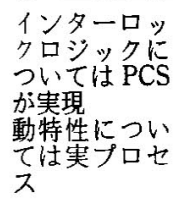 \\
\hline & $\begin{array}{l}\text { 統合コンラ(ゲー } \\
\text { トゥェイ) } \\
\text { トウ }\end{array}$ & 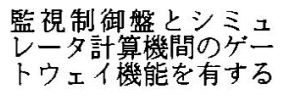 & なし \\
\hline & $\begin{array}{l}\text { インス ス ラク } \\
\text { 夕計算機 }\end{array}$ & 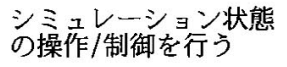 & なし \\
\hline \multirow{2}{*}{$\begin{array}{l}\text { プラン } \\
\text { トテ年 } \\
\text { タ取集 }\end{array}$} & $\begin{array}{l}\text { 工稆管理用計 } \\
\text { 算機 }\end{array}$ & $\begin{array}{l}\text { 各施設のデータを収集 } \\
\text { 監視する }\end{array}$ & 実機同等 \\
\hline & $\begin{array}{l}\text { 当直長業務支 } \\
\text { 援用計算機 }\end{array}$ & 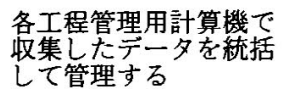 & 実機同等 \\
\hline
\end{tabular}

ど)，監視制御盤(画面制御)，工程管理用計算機(施設デー タベース)に関するものであり，それらの機能切替えの概 念図を第10図に示す。

切替えはインストラクタコンソールから要求する。切替 え先の施設コードを，シミュレータ計算機が受け取ると， その施設のロジックおよびプロセスモデルの格納されてい るデータベースへとアクセスが切り替わる。工程管理用計 算機についても同様に，データベースへのアクセスを切り 替える。また，監視制御盤では切り替え先の施設のテータ ベースがメモリーにロードされる。このように，訓練対象 施設のデータベースへのアクセスを切り替える方式を用い ているので，訓練対象施設を追加する場合には，そのデー タベースを追加するたけで佥むことから，拡張性に優れた 施設切替えの方式であると言える。

\section{（2）異なる施設間での連携訓練}

本シミュレータは，第 9 図に示したように，同じ機能 を備えた 2 系統(A/B系)から構成されており，いずれむ 5 施設の模擬が可能である。したがって，A系とB系で 互いに異なる施設を模擬させれば，施設間での連携訓練が 可能である。この場合は, 施設間でインターロック信号と ブロセス値を互いに送受信することになる。現状ではこう したインターフェイスのとられている施設間連携の組合せ は，(a)せん断・溶解施設と高レベル廃液ガラス固化施 設，(b) 分離施設と高レベル廃液カラス固化施設，の 2 パ ターンである。

連携訓練の概念図を第11図に示す。この例では A 系の タンク V11 から B 系のタンク V12 に液移送を行う際に, まず B 系から移送許可のインターロック信号を A 系に送 る。A系で許可信号を受け取ると，ポンプを起動してB 系に移送液のプロセス値を送る。B 系はそのプロセス値か

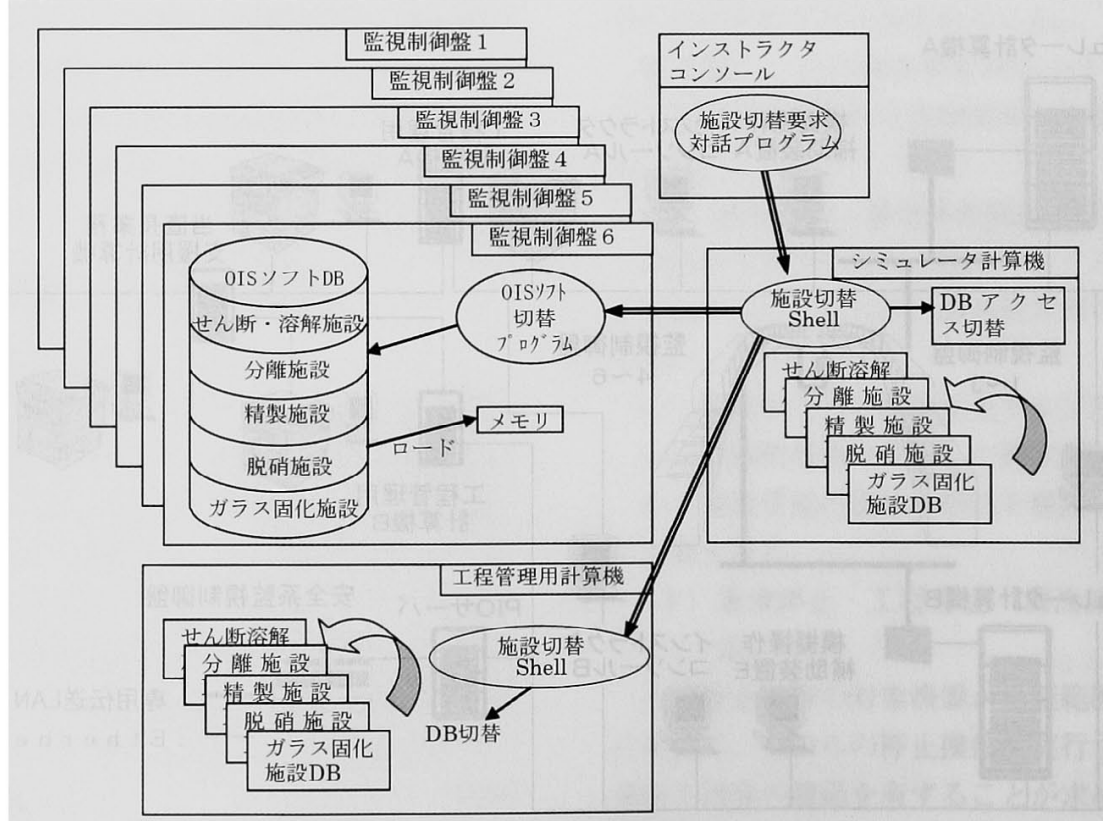

第10図 運転訓練シミュレータにおける模擬施設切替えの概念図 


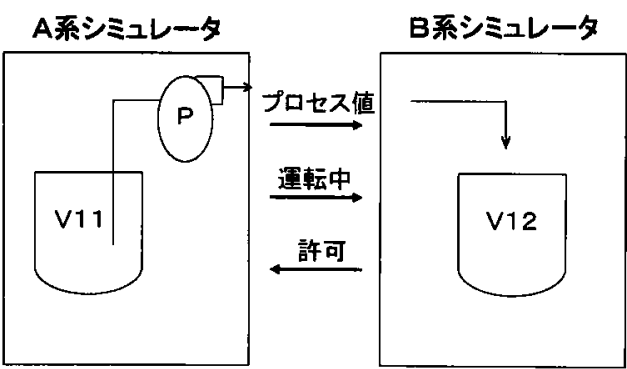

第11図 施設間連携訓練の概念図

ら,タンク液位などの OIS 表示值を更新する。

(3) 訓練速度の変更

訓練対象となる事象には操作完了まで数日を要するよう なものもある。たたし，一般に時間がかかるのは運転操作 を要しない操作の合間(例えば, 移送機器起動後の払い出 し完了までの時間)であることから，このような場合には シミュレーション速度を実時間に対して加速することによ $ク$ ，全体の訓練時間を短縮させて，効率的な訓練が可能に なる。

この加速割合を変えることにより訓練速度を変更でき る。プロセスモデルに関しては, 1 回の処理周期内で処理 する演算回数をこの加速割合分たけ増加させる(その割合 分たけのタイムステップを更新させるため)。インターロ ックロジックに関しては，タイマーをその割合分加速させ る。変更はインストラクタコンソールから，最大 30 倍ま での速度変更が可能である。

\section{3. シミュレータ開発・保守ツール}

今後, 試運転や操業開始後の実機データを反映するため に, シミュレータの調整・改造といった保守作業が必要に なってくることが考えられることから, 各種の保守ッール が用意されているが，代表的なものを紹介する。

（1）インターロックロジック保守ツール

インターロックロシックとしては, 実機相当のものがシ ミュレータ用に自動変換されてインストールされている が，これらのロシック編集や，リアルタイムでのロシック 実行状況の監視ができる OED(Object Editor Diagram)と 呼ばれるッールがインストールされている。OED はイン ストラクタ用パソコンから利用可能であり，画面を用いた 編集機能，リアルタイムでのロジック監視機能などを備え ている。

（2）プロセスモデル開発・保守ツール

今後収集される実機データの反映や，実機改造，あるい はシミュレータの機能拡張などに必要とされるプロセスモ デルの変更や保守を支援するツールとして，オブジェクト 指向に基ついたモデリングッール MDS (Model Description System)を，一部の工程のモデル作成に試験的に導入 して，その適用性を評価した。

MDSによるモテル作成の流れを第12図に示す。まず，

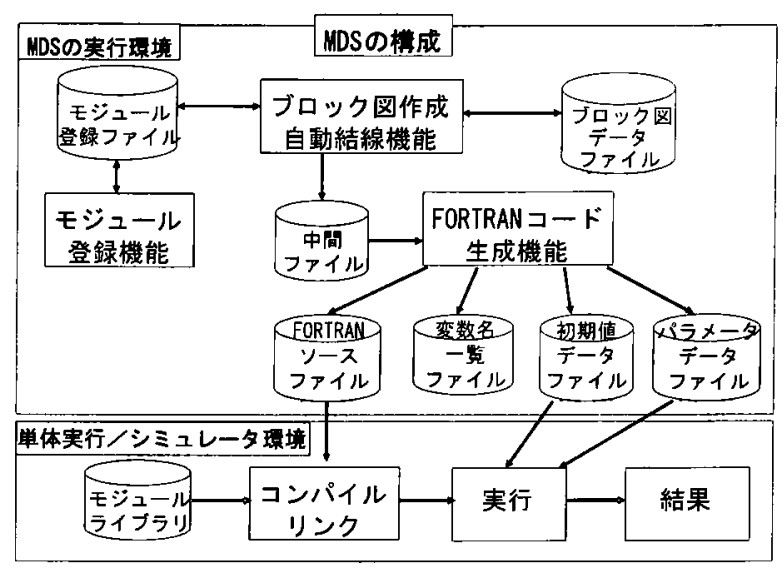

第12図 MDSを用いたブロセスモデル作成の流れ

モデルを構成する機器を部品化して登録を行う。この部品 （モシュール）には入出力情報と処理情報（処理をプログラ ミングした Fortranのサブルーチン相当)が含まれてい る。登録した部品を編集画面上に配置して, 部品(機器)間 での結線を行うことにより, 工程のシステムを組み上げ る。そして，各部品に必要な初期値設定を行う。

これらの作業が終了すると, システム全体のFortran コードを自動生成する。自動生成されたコードをコンパイ ルすることにより実行モジュールを生成すると，MDSの コントローラを用いて，モデル単体で実行することが可能 となる。このように入力パラメータの初期值を任意に編集 し, モデル単体で実行して, 出力パラメータのトレンド表 示を行うことにより，作成したモデルの妥当性が確認でき る。モデルの妥当性が確認されたら, モデルのFortran ソースコードをシミュレータにインストールして，コンパ イル・リンクすることにより, MDS で改良したモデル機 能をシミュレータに反映することが可能である。

なお，MDSを用いたモデル作成評価に関しては，次章 で述べる。

(3) パラメータ変更ツール

モデルパラメータの変更は MDS でも可能であるが，モ デルのソースを修正せずにデータ值を変更するだけで，変 更が可能なパラメータに関しては，インストラクタコン ソールから变更が可能である。

ここで変更できるパラメータは運転状態に依存しない機 器固有のパラメータ(ポンプ定格流量など)であり，通常の 運転初期設定データとは異なるデータベースに保存される ため, 運転の初期状態を変更しても，これらの值は変更さ れない。

変更はシミュレータデータベースからインストラクタコ ンソール(パソコン)に現行值をダウンロードして行う。変 更ツールは表形式で工程番号や機器名称, 変数の内容とそ の単位，および現在設定されている値を表示しており，変 更作業をわかりやすくしている。变更が終わると，修正し たデータベースをシミュレータのそれにアップロードする 
ことにより，シミュレータのパラメータ値が変更される。

VI. シミュレータの実運用と訓練

本章では，まず試験的に導入したモデル開発・保守ッー ルによるモデル作成の手順を説明して，ッールの適用性評 価を行う。そして実際に行った訓練の概要を紹介すること により，シミュレータ導入の有効性について述べ，最後 に，今回の保安訓練シミュレータ開発と訓練の経験を踏ま えた上での，今後の展望と展開について述べる。

1. 開発・保守ツールを用いたモデル作成

今回，一部の工程設備を対象として，MDSを適用した モデル開発と，そのモデルのシミェレータ本体へのインス トールを行い，MDSの適用性を評価した。

モデル開発・保守ッールを用いたモデル作成・調整とシ ミュレータ本体へのモデルインストールの流れを第13図 に示す。今回はせん断・溶解施設の清澄・計量設備を対象 に，モデル開発・保守ッールの適用性評価を行った。清 澄・計量設備には遠心清澄機と呼ばれる再処理施設特有の 機器がある。まず，MDSでモデル作成を行い，単体テス トにより工程のプロセス挙動の妥当性を確認する。その後, MDS で作成したモデルの Fortran プログラムソースと定 数・初期值をシミュレータ本体にインストールして，シミ ュレータのインターロックロシックと組み合わせ，シミュ レータ全体としての応答を確認する。ここで清澄・計量設 備のモデルは，すでに従来手法，すなわち人手によるコー ディングでソースコードを作成したものが存在するが，こ の従来手法によって作成されたモデルと同等の応答が得ら れることを，工程の起動・停止操作を通して確認した。

また，逆にシミュレータ本体で使用している初期値デー タをダンプして，モデル開発・保守ッールにインストール することも可能である。この機能により，シミュレータの

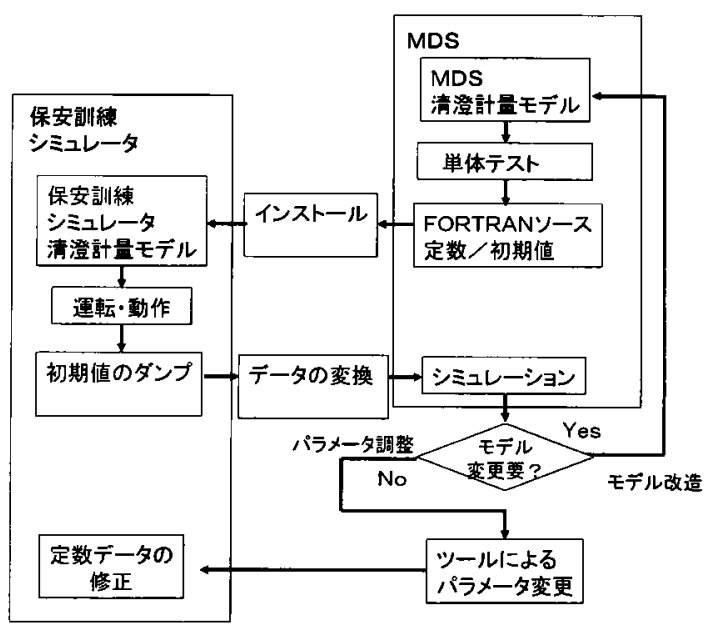

第13図 モデル開発・保守ッールを用いたブロセスモデル作 成・調整の手順
用いている初期値に対して，MDS 側で自由にパラメータ サーベイを行うことにより，実機応答に合わせるチューニ ング作業が効率的に行える。チューニング作業により調整 されたパラメータ值は，パラメータ変更ツールを用いてシ ミュレータ本体へ反映することができる。

以上の適用検討により，以下の評価結果が得られた。

（1）MDSで作成したモデルと従来手法によって作成さ れたモデルでは，起動・停止操作に対して同様のシミ ュレータ応答が得られ，MDSによるシミュレータモ デル作成が可能であることが確認された。

(2) 再処理プロセスで使用される特殊な機器のモデル 化, シミュレータへの組込みにすMDS は適用可能で あることが確認された。

(3) シミュレータ本体の初期值を MDS 側に逆にインス トールすることが可能であり，MDS 単体計算により シミュレータチューニングが効率的に行えることが確 認された。

（4）すでに作成されているモデルを，大幅な変更を行わ ずにMDSの部品としてモジュール化することが可能 であり，プログラム資産が有効利用できることが確認 された。

(5) パラメータ変更ツールを用いて，シミュレータモデ ル定数を表形式で編集・変更することにより，シミュ レータシステムへ反映することが可能であることが確 認された。

(6) 反応器モデルは, 単体でもそのモデル構造が大変複 雑になるため, 機器モデル内の各種の演算部分を可視 的なモシュールとしておのおの登録し，モデル内を階 層的なモジュール構造とすることが今後必要となる。

（7）ユーザーインターフェイスに関しては，使いやすさ の観点から必要な改良点などが課題として抽出された。

\section{2. 運用後の訓練内容と実施状況}

保安訓練シミュレータを用いた訓練は2003年 8 月から 開始し，現在も継続中である。すでに運転クルーに対する 1 回目の教育・訓練が完了して，2003年末現在で，約 200 名にのほる訓練実績を上げている。

これまでの訓練は，

- 基本動作（報告·指示 ·指差呼称など)の体得

・チームワークの醇成

といった「運転の基本」の習得に重点を置くことと，

- 異常時対応操作フローの理解

を当面の訓練目標として進めてきた。

また，現在の訓練実施要領は以下のようになっている。

・施設ごとの運転班単位で実施

- 訓練事象のうち溶解液漏洩事象, 混合酸化物貯蔵建屋 外電喪失事象など 8 つの異常事象を実施

- 1 事象当り約 40 分, 1 回 6 時間の訓練を実施

実際の訓練風景を第14図に示す。 


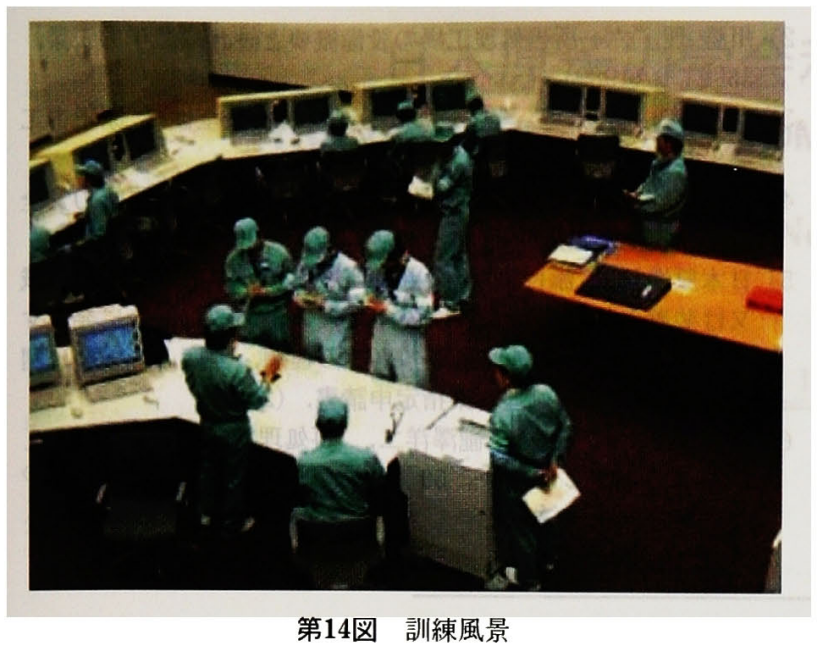

これまでの訓練を通じて以下のような成果や経験が得ら れた。

（1）訓練後のアンケートにより，特に基本動作の定着な どに対してシミュレータ訓練が有効であることが確認 された。

（2）大半の運転員がシミュレータによる運転訓練が初め てであった中で，シミュレータ訓練自体が定着化した。

（3）訓練を通じて，運転員が特に陥りやすいヒューマン エラー事例がいくつか抽出されたが，それらの発生防 止を図るため今後の訓練に反映する。

(4) 操作ミスの中で, 実機での操作機会の少ないものに 関しては, その発生防止のためにはシミュレータによ る訓練が特に有効である。

（5）安全評価上の運転員対応の必要性に着目した今回の 訓練事象選定手法は，重大な操作ミスを防止する観点 から妥当なものである。

（6）運転員が試験運転を通じて蓄積している触手経験 を,さらに補完するうえでシミュレータによる訓練が 有効である。

\section{3. 今後の展望と展開}

運転訓練シミュレータ開発の展開を第 2 図に示した が, 再処理工場操業開始後の安定運転に向けて, 総合運転 訓練シミュレータを操業 2 年後を目標に設置する予定で ある。

総合運転訓練シミュレータは保安訓練シミュレータを継 承発展させ, 試験運転を経験できない操業後配属運転員の 養成を主眼として開発するシミュレータである。通常運転 におけるプラントの起動/停止訓練, 異常事象への対応訓 練, 施設間の連携や統括当直長も含めた包括的な訓練を行 うとともに運転技術の継承を図り, プラントの安定運転, 生産性の維持・向上を目指す。

以上の目的を満たすために, 保安訓練シミュレータにお ける模擬範囲からの施設 · 工程 ·機器などの更なる拡張
や，異常訓練事象の拡大などを含めて，訓練シナリオおよ びプロセスモデルの大幅な改造 ·追加が必要になる。ま た, 試験運転や操業運転を通じて得られたプラント特性を 反映し，実機模擬精度の向上を図る必要がある。

このように総合運転訓練シミュレータの開発規模は今回 開発した保安訓練シミュレータに比べて大幅に増加するた め, 保安訓練シミュレータ開発の経験を活かした効率的な 開発を進める必要がある。そのための課題としては, 下記 のような項目が挙げられる。

（1）訓練事象の明確な選定基準と選択

(2) 訓練シナリオ展開の効率化

（3）訓練シナリオに基づいた模擬範囲の明確化

（4）フフログラムソース管理の効率化

(5) 開発・保守ツールを有効活用したモデル開発の効率 化

(6) シミュレータ動作確認試験およびモデル・ロジック 結合試験の効率化

これらの課題を解決しつつ, 総合運転訓練シミュレータ の効率的かつ完成度の高い開発に取り組む。

\section{VII. まとめ}

六ヶ所再処理工場における運転訓練シミュレータ開発計 画の第 1 フェーズである保安訓練シミュレータの開発. 設置を行い，2003年 8 月から訓練を開始した。

運転訓練シミュレータの開発に当っては, 運転訓練の目 的・ねらいを十分吟味し, 優先的に訓練を開始すべき異常 事象の選定を安全評価の知見に基づき行った。また今後開 発予定の総合運転訓練シミュレータへの継続的な拡張可能 性を考慮した上で, その基本構成を検討 ·設計した。シミ ュレータのプロセスモデルの開発・作成に当っては, 試験 データや操業開始後の実機データに基づいたパラメータ調 整やモデル改造が予想されることから, 保守性を考虑した モデル開発・作成の手法を検討し, 一部の工程に対して適 用・評価を行った。

運転訓練シミュレータ設置直後に開始された訓練では, すでに運転クルーに対する 1 回目の教育・訓練が完了し て, 約200名に上る訓練実績を上げている。その結果, 基 本動作の体得には本シミュレータは非常に有効であること が確認された。また訓練を通じて, 運転員が陥りやすい操 作ミスが抽出され，今後発生防止に向け訓練へ反映する。

再処理工場操業開始後の総合的な運転訓練に供するもの として開発予定の総合運転訓練シミュレータでは, 今回設 置したシミュレータ設備を有効活用して, 模擬対象施設や 機器の拡充, 実機運転手順に沿った通常運転訓練を可能と する拡張, 模擬対象異常事象の充実, 実機データの反映に よる精度向上などを目指している。このために, 今回試験 的に導入したモデル開発・保守ツールの評価を重ね, グラ フィックモジュールを用いたモデル作成ッールを全面的に 導入し, 開発・保守の効率化を図る必要がある。今回の試 
験的導入評価ではツールの有効性が確認され，同時に効率 的に利用するための課題点なども抽出できた。

今回開発・設置した運転訓練シミュレータは，使用済み 燃料再処理施設の運転訓練シミュレータとしては世界でも 例を見ない初めての施設である。六ヶ所再処理工場の安全 かつ安定な操業に向けて, 運転員の技術・技能向上に本シ ミュレータを有効活用する所存である。

$$
\text { 一参考文献一 }
$$

1）住谷 寛, 竹内 化, 佐々木貞明, “再処理工場開発の現状, " 原子力工業, 38 [10], 10 (1992).
2) 川勝 理, “六ヶ所再処理工場の設備概要と設計, ”原子力工業, 35[9], 9 (1989)

3）住谷 寛, 川勝 理, “六ヶ所再処理工場の安全性,”原子力工 業, 35[9], 24 (1989).

4）原子力安全委員会, “再処理施設安全審査指針,”原子力安全 委員会安全審查指針集 改訂11版, 770 (2003).

5）日本原然㧣，“添付書類八 再処理施設の操作上の過失，機械 又は装置の故障，浸水，地震，火災等があった場合に発生す ると想定される再処理施設の事故の種類, 程度, 影響等に関 する説明書, ”再処理事業指定申請書, (2002).

6) 中村健二, 荒月秋雄, 瀧澤洋二, “再処理施設運転訓練シミュ レータ,"東芝レビュー, 59[7], (2004). 